\title{
(1) Of God and Gadamer
}

\author{
Bruce Bain \\ Professor \\ Department of Educational Psychology \\ University of Alberta
}

It seems that in each generation of intellectuals there are some who continue that tiresome tradition of urging others to accept the prevailing myths from which they claim there is no escape. I wish I were wiser, then perhaps I would understand the reasons for this apparently eternal practice of putting old wine in new bottles. By now that wine must surely be pretty sour. Then there are others who recognize that the prevailing myths are convenient fictions whose main function is to ensure the status quo. My essay leaves no doubt who I think are the apologists and who are the myth busters. I was born and raised in Montreal, where I went through metamorphoses from junior high second language teacher to graduate student to clinical psychologist. Following a doctorate focusing on Merleau-Ponty's insights for a cross-cultural psychology, and junior professorships in Uganda, France and Hong Kong, I've tried to continue Merleau-Ponty's brand of technical-eclectic phenomenology, coupled with his concern for social justice. Claims of success would be premature.

Once upon a time when the world was young, people believed in deities. In those days the only One-or, in some cultural traditions, the only Ones-who had the ability to see things as they truly are were the Gods. Now the world is no longer young and people have moved on to other things, leaving divine things to the divines and mortal things to mortals. Predictably, some mortals aspire to the divine and claim for themselves the power of immaculate perception.

In an amazing turn of scholarly humility, some of these jumped-up mortals are philosophers or, to be precise, one group of philosophers, claiming a universal ability for unblemished perception, a power uncontaminated by the everyday things of the human condition. In the old days these philosophers would have been called heretics and burned at the stake. Today they call themselves hermeneuticists and demand recognition of their gift.

One could, I suppose, center on the illuminati popularus of the moment, Derrida, a conceptual stepchild of Gadamer, but this would be blaming the unacknowledged child for the sins of the father. It is also evident, at least to me, that the writings of Derrida are a melange of magnificent aphorisms woven together by a patina of high-IQ echolalia. Gadamer is

Phenomenology + Pedagogy Volume 91991 


\section{University of Alberta}

the deep thinker; himself a legitimate conceptual child of Heidegger, a central figure in contemporary existential thought.

I begin my brief analysis by situating Gadamer in the historical currents of his times. I do not address his ideological conservatism, nor the reaction of his more progressive contemporaries, for example, Sartre, Foucault, Habermas, Merleau-Ponty, de Beauvoir, Freire, Marcuse, and others, who had little patience with the reflection of a supine conservative Weltanschauung in Gadamer's philosophy. A dissertation remains to be written on the theme of why ideological reactionaries start their theoretical analyses assuming the primacy of the individual, and ideological progressives start theirs assuming the primacy of history. I end with thematic heuristics that might guide us toward a modern conceptualization of the relationship of language, perception, and reality, thus resolving some of our enduring educational and philosophical dilemmas.

\section{Gadamer's Hermeneutics}

I will not treat the whole of the German hermeneutic tradition to a critical analysis; this has been done superbly by Bernstein (1983). Nor will I treat the much older Eastern hermeneutic tradition of Li Ehr, Yu T'ung, and other wise Taoists; although I lament the total absence of this subtle body of genius in the hermeneutic tradition represented by Gadamer and the German School. The Eastern tradition's recognition of perception as an original synthesis of subjectivity, objectivity, and vehicle of meditation (word, icon, or some other symbolic form), has been well articulated for centuries. The German School, running from Herder to Humboldt to Husserl to Heidegger to Gadamer, generated a vast literature attempting to reconcile the Cartesian split between subjectivity and objectivity, missing the point that their formulations were bound by a limited cultural Weltanschauung. Their lengthy treatises on this problem are characterized by attempts at bridge building between two halves of a whole that ought not to have been dissected in the first place. A certain ontological and epistemological ecumenism could have resulted from the simple expediency of reading the Eastern savants.

With the publication of Wahrheit und Methode (Truth and Method, 1960, pp. 33-47), Gadamer argued for "a philosophy consisting of interpretation of philosophical tradition." He grounded this argument in a general theory about "the universal ontological significance of the phenomenon of understanding." "Art makes no less a claim to truth than science," according to Gadamer. The reason science has been accorded priority has been "the false dichotomy of art and science." Once we discover how truth can happen in art, according to Gadamer, "we will see that truth is neither subjective or objective, but is historically situated in events where interpretive horizons are 'enlarged' and 'fused' with past experience." Past experience is especially important for Gadamer; but this is not personal past experience; it is that of authority and tradition that "needs to be affirmed, embraced, cultivated." In even the most intimate of 
perceptions, according to Gadamer, "far more of the old is preserved than anyone knows." Gadamer is thoroughly enshrouded in the Platonic concept of eternal Logos, ignoring the evolutionary thrusts of personal and collective history.

Gadamer's thesis owes more to Classical Romanticism than it does to Emancipatory Hermeneutics as advocated by Gramsci, Foucault, Freire, Apple, Tosi, Illich, Merleau-Ponty, and other modernizers of this ancient craft. Gadamer (1960, pp. 15-29) is constantly urging us "to emulate Socratic virtues" and to "a critical appropriation of the traditions that have shaped us." His motivation is to "foster a re-awakening consciousness of solidarity of a humanity that slowly begins to know itself as humanity." These are admirable goals. But the genesis of humanity and the process of achieving it-or being denied it-is the real issue for modern educators and other students of the human condition.

Gadamer's approach, following one of his mentors, the 18th-century Protestant theologian and interpreter of religion to the romantic world, Friedrich Schleiermacher, is an appeal to intuition: one feels it to be thus and such, and therefore it is; the antithesis of Descartes' cogito. As a statement of one's personal experience, yes, such a claim would have a certain validity. But personal intuition or verstehen is too cluttered with existential and ontogenetic experience to serve as the basis of a general theory. Both Descartes' "I think therefore I am," and Gadamer's "I feel therefore I am," are essential to any conceptualization of the human condition; independently they are pars pro toto, one side is taken for the whole.

Some of the contextualizing difficulties in this view stem from the cultural Weltanschauung of which Gadamer is Knight Exemplar. The Romantic thread in this Weltanschauung included a belief-and I stress belief-in the call for humans to return to their true nature, which was not a simian primitivism or a Descartean robotism, but a genuine cultivation of inherent ennobling capacities. This Rousseauean view had it that essence not only preceded but exceeded existence. Hence being human was a condition with which one is born, and the civilized life was a matter of creating outer forms that are in concert with inner revelations. In their supernal form, always a concern of the German Romantics, the chosen among us could create themselves in the image of higher beings. In addition to finding expression in the works of Gadamer, this romantic cum primitive religious view repeats itself in the artistic and anthropological quests of Goethe, Wagner, Humboldt, Schleiermacher, and of course Gadamer's other great mentor, Heidegger. This Weltanschauung, which has roots in German mysticism and folklore, runs counter to the prevailing, and I believe more propaedeutic, modern view best expressed by Sartre, "that existence precedes essence," that being human is not a status with which but to which one is born. 


\section{University of Alberta}

Another thread in this Weltanschauung concerns language and subjectivity. Humboldt, along with Plato, Vico, Saussure, Jacobson, Vygotsky, and Hymes are perhaps the few who have said anything that is new and comprehensive about language. Humboldt's Man's Intrinsic Humanity: His Language (1830-1835) gave eloquent voice to the idea that language is not ergon but energia. "Language has to be seen as a constant process of creation and re-creation," (p. 3) according to Humboldt. Humboldt ignored Hegel's and Marx's injunction "to base this process on social and material foundations," and projected this idea of activity into a mellifluous blend of romantic and idealist symbolic forms: folk spirit, the nation, the people, and other mystical-arcane forms of collective consciousness-all operating outside of history.

The idea was that these abstract creative capacities are separate from material and social practice, leaving the individual to be defined as creative subjectivity, the starting point of meaning. What is missed in this romantic eulogy of subjectivity is that the consequences of subjectivity must be evaluated in terms of their historical consequences. There have been great moments in the history of civilization: when Leonardo created depth perspective and revolutionized art; when Einstein turned the physical universe inside out; and many other examples of subjective challenges to prevailing beliefs-all judged by history.

Subjective verstehen coupled with the manipulation of symbolic forms has created the heights of personal and collective visions for which civilization is richer, wiser. The same process, however, has also created stupidities the likes of which no dumb dog could ever dream. For example, in Gadamer's own time there was the horror of the German National Socialists; in contemporary times there is the Rushdie affair; and throughout history there have been numerous large and small examples of subjectivity run rampant. The contemporary Reign of the Zealots in Iran-to put it mildly-should be sufficient to provoke serious reflection about an uncritical acceptance of subjectivity as the sole basis for change in belief or practice. Any call for social or educational change based on a subjective denial of history is bound to produce a denigration of the human condition.

A less dramatic call, but one that is equally pernicious in its implicit alienation of others of a different race, nation, or language, has long been advocated by certain positivist researchers. For example, Sapir (1921) and Whorf (1956) naively popularized some of Humboldt's notions in the form of hypotheses concerning how language determines thought and perception. Their empirical orientation toward questions of ontology and research, which carries a certain misguided sense of solidity among the nonreflective, has been sufficient to carry them through the obvious criticisms of their hypotheses by generations of ethnographic researchers (see Cole \& Scribner, 1974). Other researchers, although of a more humanistic orientation, nonetheless used the same Humboldtean meta- 
phor. For example, Heidegger (1971, p. 190) argued that "language itself is-language and nothing else besides." What all these extensions of Humboldt's view have in common is the idea that language is an independent reality. It is a hidden God that acts in our place and to which we must submit. Heidegger goes so far as to suggest that "man speaks only as he responds to language," (1971, p. 210) a view that renders the intentionality of the communication between people nonconsequential.

The modern view that perception is grounded in language, and language is grounded in intentional social relations is ignored in these mysticalromantic formulations of a particular German Weltanschauung.

Heidegger (1971, p. 146) continues with the Humboldtean metaphor by insisting that "man acts as if $h e$ were the shaper and master of language, while in fact language is the master of man," the idea being that we dwell in language, not in a social world mediated by language, perception, and existential experience. How the bi- or multilingual person would ever come into being, or how one could even acquire another language, or how there could even be another language, not coincidentally, is ignored in these formulations of Humboldt, Heidegger, Gadamer, Sapir, and Whorf. Their Weltanschauung, in its rush to justify cultural beliefs in "nation" and "folk spirit" and other such subjective fancies, simply failed to recognize that language is neither ergon nor energia; it is simultaneously immanent and transcendent.

Moreover, on this crowded planet of ours, we do not speak one language, we speak 2,000 or 3,000 languages. Any philosophy of language that confounds actual diversity with equivalence (as have such disparate thinkers as the Kabbalists, the Pietists, Chomsky, and Heidegger) simply perpetuates the old biblical myth of a Language of God, one ideal form, and many vulgates, many distortions, after Babel. The question of diversity of languages, including bi- and multilingualism, is simply not resolved by a reversion to ancient Mesopotamian mythology.

By raising subjectivity to the level of determiner of personal and theoretical meaning, Gadamer carries on an old cultural tradition, one laden with fanciful myths and nationalist ideologies from its own romantic history. Let me suggest another path-let us temporarily call it an "emancipatory path"-which has the promise of grounding the problem of language and perception in more of a contemporary Weltanschauung-one that exists in personal and collective history. Above all, let us remove these matters of people, language, and perception from the realm of le mystère suprême and center them in human affairs.

\section{Two Axioms and Some Nudges Toward a Contemporary Weltanschauung}

Axiom one. There is no such thing as immaculate perception. Subjectivity is an inappropriate basis for a general theory as perception is always motivated by knowing consciousness-by a particular self in a particular moment in lived time-with all the vagaries of personally schematized 


\section{University of Alberta}

knowledge in a particular context. It could be argued, I suppose, that regardless of the type of meaning, it is nonetheless perceived meaning; but this would suggest that, with regard to historical value, meaning can be everything or nothing, which is surely a paradoxical and specious claim.

There are those who are more spontaneously astute or intuitive about what they are experiencing, but not all perceivers are equally perceptive; and the same individual can be insightful in one setting and reduced to bewilderment in another. The naive young child and the informed adult looking at the same set of objects will see quite different things; and in most cases the adult has the better grasp of the whole situation. For good reason the whole of child rearing, pedagogy, and relations between those who are informed in a specialty area and those who are not is based on this seeming contradiction. Those who believe to the contrary, for example, Gadamer, the most articulate of the romantic-idealist hermeneuticists and its leading exponent, are fundamentally in error. They have misunderstood perception. Perception is of something by someone, and the relational dynamics are mediated by factors of ontogenesis, language, and the contextualizing situation.

Axiom two. In the area of human affairs, there are no universal or eternally acceptable methods or concepts. There is only a rational attitude, and methods and concepts that are appropriate for particular historical epochs and research interests. Philosophers like dabbling in the realm of universality. It lends feelings of importance and eternity to an otherwise sterile existence. Scientists, however, especially those in the human science of education, have long since recognized the irrational basis to claims of One Eternal Method. Even Marxists of the contemporary variety no longer ascribe omnipotence to the General Laws of Scientific Socialism. By proposing a universal approach to questions of philosophy, based on a general theory about the universal ontological significance of the phenomenon of understanding, Gadamer ascribes to one method the position of Expede Herculem.

Gadamer's (1960, p. 6) allocation of universality to "the phenomenon of understanding" violates both axioms. No argument will be put forward that "a phenomenon of understanding approach" is invalid as a specific theory. To the contrary, any account of perception must include recognition of individual meaning. The problem is that, as formulated by Gadamer, personal perception has been uncritically attributed with a Platonic form of Logos. There is also a practical difficulty here: the Achilles heel of Gadamer's type of hermeneutics is that truth claims based on verstehen are at best uncertain, problematic. By definition there can be no criterion or canons of veracity. This is complicated by the fact that perception, in addition to whatever else it may be, is a personal projection: one sees something of oneself in all perceptual acts. Only an 
extreme Platonist or a self-proclaimed prophet would accept individual mind as a basis for a general theory.

The crux of contemporary problems in philosophy, psychology, and education concerns questions of epistemology and the relation of language, perception, and reality. The ideas of Merleau-Ponty (1973) and Vygotsky (1962) must figure prominently in any contemporary solution. Let me try to reduce the complexity of their ideas to some orderly, manageable principles.

Merleau-Ponty and Vygotsky suggest that humans live in two realities: the concrete world of objects and events deployed in space, time, and motion bound together by physical, psychological, and logical relationships; and the social-ideation world of language.

Both realities come into being as a consequence of intentional relations between caregiver and child. Hence, in the object world and in the world of language, there is always a certain emotive, psychological element: Neither is independent nor pure in form; there is always a certain projection of the perceiver in language and the object world. Self, language, and object-as an experienced unity - constitute lived experience. Although describable independently of each other, they are experienced holistically. The developmental project for each child is one of constantly differentiating this whole world and reintegrating it into ever more sophisticated forms. Under the intentional direction of the caregivers, being pulled this way and that by the intrinsic attraction of the objects, the speaker and the speech, the child eventually reaches a point where reflection of one reality on the other is possible. The realities of the concrete world and of language are thus not eternal ideal forms. Language is a social means of conception, perception, and belief-one which pulls the concrete world into being-and, conversely, forces new demands for linguistic forms to do justice to experience.

At the level of each individual, in its genesis, language for others precedes language for the self. Language originates in social practices; and over the course of ontogenesis, it is internalized and used for various social, practical, and personal uses. For specific objects, events, and relations to come into being, they must be perceived; and to be perceived, they must be signed in some form or other. Ultimately, the concrete world is dependent on social process. But the language or languages one acquires are also molded on practical, material experience and become a means to triumph over the concrete world.

Given these fundamental concerns with the sociogenesis of human experience, Merleau-Ponty (1973) and Vygotsky (1962) go on to deal with the problem that plagued Humboldt and those in his wake. Using a philosophy of common sense approach, Merleau-Ponty and Vygotsky suggest that at the level of lived experience, the concrete reality is treated as the basic reality. Children and adults simply assume that the world of objects 


\section{University of Alberta}

and events is going to go on existing whether or not anybody ever talks about it. It is not dependent on mind or subjectivity.

At the same time, it soon becomes apparent to the developing child, as it is to the student of epistemology, that the two realities are not independent of each other. Where Sapir (1921) and Whorf (1954) went wrong was in their assumption that the words of language directly refer to concrete reality - on an analogy with the way a map refers to a terrain. The issue of language determining perception aside, this is mistaking the lexical items in a dictionary for concrete reality. Where Gadamer (1960) went awry is in the assumption that the language one uses as an aid to perception can be fully bracketed, allowing unfettered perception of the phenomenon. The notion of immaculate perception denies the very linguistic and social dynamics that permit human perception in the first place.

We come closer to modern questions of epistemology with MerleauPonty's and Vygotsky's recognition that there are no independent rules for codifying concrete reality, including the concrete reality of language. There are rules for making statements: these vary by cultural, gender, class, and other types of historical experience-in various languages. Language is not singular, ideal, eternal. That these rules are constantly being reconstituted can be observed from a casual glance at speech use in the English language from Chaucer to exchanges in departmental meetings between otherwise intelligent professors. As a practical matter, hermeneuticists do not help their cause by conducting inordinate etymological reviews of "the real meaning" of a word, because at no point in history should we assume that there was a better or truer relationship of a word to a thing. Modern studies of language use clearly indicate that the rules of language at best tell us about the relationship of words to other words: they are rules of composition, not description.

An utterance can, of course, describe a reality. But it does so not by standing as a direct or analogical model of the reality in question. It does so by luring the listener's attention to the organization of the perceived reality as articulated by the speaker. Following the terminology of semiology, these rules are systems of signifying gestures by which a speaker points out a certain reality to a listener. It is important to note that for Merleau-Ponty and Vygotsky the reality to which the gestures call attention can be imaginary or abstract or concrete, the important point being that in any perception and communication thereof, there is a dual determination: The structure of perceived reality determines what is to be said, while the rules of a particular language in a particular context determine how it is to be said. The felt experience of bi- or multilingual persons changes in subtle ways as they try to characterize the perceived world with the rules of one language or the other, suggesting that self is always integral to experiences of the worlds of object and language. 
By trying to understand the meaning of utterances detached from their contexts, as Sapir and Whorf have done, or by giving perceived meaning the status of fundamental essence, as Gadamer has done, we find ourselves in all manner of theoretical and practical difficulties. Until we recognize that perception is not pure process encountering pure essences, and that words and related gestures do not have independent meanings, we will remain in Humboldt's trap. Self, language, and the perceived object world differentiate and reintegrate in predictable ways over the course of ontogenesis, but at no time are they independent of each other, nor outside of individual and collective history.

\section{Quo Vadis?}

The modernizing heuristics offered here are more thematic than specific. They contextualize Gadamer's tradition, but in doing so raise many questions that remain to be answered. There is, nonetheless, a contemporary Weltanschauung here, one that will allow us to create narratives that will modernize our anthropological, philosophical, and pedagogical crafts. Gadamer fought the battles of his time, and within his culturalhistorical experience offered his solutions. But let us not throw out the baby with the bathwater. How to integrate some of Gadamer's specific insights, for example, "horizon fusion" and "personal meaning," without all the bizarre baggage contained in his Weltanschauung is part of our challenge. It is time to move on, to fight new battles, to ground our modernizing theses in emancipatory heuristics. Perhaps our quest should be less with Humanity and the Gods, and more with the concerns of people in society-writ in smaller letters.

\section{Acknowledgment}

The author wishes to thank Dr. Anatol Pikas, University of Uppsala, Dr. Bob Soloman, University of Alberta, and Dr. Agnes Yu, Edmonton Public Schools and the University of Alberta, for their comments on an earlier draft of this paper. The graduate students of Ed. Psych. 513, Language Cognition and Bilingualism, deserve special recognition for their vigorous and caring debates on these important matters.

\section{References}

Bernstein, R. (1983). Beyond objectivism and relativism: Science, hermeneutics, and praxis. Philadelphia, PA: University of Pennsylvania Press.

Cole, M., \& Scribner, S. (1974). Culture and thought. Toronto, ON: Wiley.

Gadamer, H.-G. (1960). Wahrheit und Methode: Grundzuege einer philosophischen

Hermeneutic. Berlin: Mohr.

von Humboldt, L. (1830-1835). Man's intrinsic humanity: His language. In M. Cowan

(Ed.), (1963) Ludwig von Humboldt, humanist without portfolio (pp. 52-107). Detroit,

MI: Wayne State University Press.

Merleau-Ponty, M. (1973). Consciousness and the acquisition of language. Evanston, IL:

Northwestern University Press.

Sapir, E. (1921). Language. New York: Harcourt, Brace and World.

Whorf, B. (1954). Language, thought and reality. Boston, MA:MIT Press.

Vygotsky, L. (1962). Thought and language. Boston, MA: MIT Press. 